\title{
Some observations on growth and development of Macaca mulatta
}

\author{
By R. Heywood, Huntingdon Research Centre, Huntingdon PEI8 6ES
}

\section{Introduction}

The normal diet and growth patterns of most animals are so far removed from man as to make extrapolation of data across species boundaries a difficult, if not impossible, exercise. The phylogenetic argument that sub-human primates are evolutionarily nearer man does not necessarily mean that they are the most useful as animal models.

The nutritional requirements of laboratory monkeys have recently been reviewed by Harris (1970) and Kerr (1972). Monkeys might be of value in studying disorders of human nutrition and development, but their usefulness depends on establishing normal figures. This paper presents some data on the growth and development of infant rhesus monkeys (Macaca mulatta).

\section{Growth}

Foetal growth. The rate of growth is greatest during foetal life. Kerr, Kennan, Waisman \& Allen ( 1969 ) have reported on the physical growth of rhesus monkeys at various gestational ages. Results collected at the gestational age of $120 \mathrm{~d}$ are compared with the results of Kerr, Kennan et al. (1969) in Table I; the actual weights recorded by R. Heywood, A. K. Palmer \& J. Cooke (unpublished results) are lower, but when comparison is made of the organ weights expressed as a percentage of foetal weight there is good correlation. It is of interest to note that at day 120 the brain has reached approximately $50 \%$ of the adult weight.

Birth weight. The neonatal period is a critical time, and many factors are decisive as to whether the infant survives; not least of these factors is the length of in utero life and the birth weight. Price, Anver \& Garcia (1972) found the highest-risk group to have birth weights less than $350 \mathrm{~g}$, though a $20 \%$ fatality was recorded in infants born in the $35^{\circ-} 399 \mathrm{~g}$ group. The mean birth weight they recorded for $M$. mulatta was $470 \pm 80 \mathrm{~g}$, whereas we recorded a mean birth weight of $440 \pm 50 \mathrm{~g}$, and a gestation period of $166.8 \mathrm{~d}$, within the range of $156-177 \mathrm{~d}$.

Growth during the immediate postnatal period. Infant monkeys lose approximately $10 \%$ of the birth weight by $1.5 \mathrm{~d}$, but this weight is recovered by day 4. Kerr, Scheffler $\&$ Waisman (1969) recorded losses of up to $50 \mathrm{~g}$ by $36 \mathrm{~h}$. They reported that the rate of weight gain reached a peak value during the first month and showed a steady decrease thereafter. On a smaller sample, a steady increase in body-weight gain of about $5 \mathrm{~g} / \mathrm{kg}$ per $\mathrm{d}$ in the first 3 months, then a gradual reduction in this rate of weight increase to a value of $3 \sim 3.5 \mathrm{~g} / \mathrm{kg}$ per $\mathrm{d}$ has been recorded. 
Table I. Organ weights of foetal rhesus monkeys (Macaca mulatta)

\begin{tabular}{|c|c|c|c|c|c|c|c|c|}
\hline & \multicolumn{4}{|c|}{ Absolute weight (g) } & \multicolumn{4}{|c|}{$\%$ of body-weight } \\
\hline & \multicolumn{2}{|c|}{$125 \mathrm{~d}^{*}$} & \multicolumn{2}{|c|}{$120 \mathrm{~d} \dagger$} & \multicolumn{2}{|c|}{$I 25 \mathrm{~d}$} & \multicolumn{2}{|c|}{$120 \mathrm{~d}$} \\
\hline & Mean & $\mathrm{SE}$ & Mean & $\mathrm{SE}$ & Mean & $\mathrm{SE}$ & Mean & $\mathbf{S E}$ \\
\hline Total body-weight & 295 & 27 & 214 & 42 & & & & \\
\hline Placenta & I 14.8 & $21 \cdot 3$ & $67 \cdot 4$ & IO 3 & $3^{8 \cdot 8}$ & $5 \cdot 9$ & $32 \cdot 7$ & $8 \cdot 9$ \\
\hline Brain & $4 I \cdot 2$ & $3 \cdot 6$ & $3 I \cdot I$ & 4.0 & 14.0 & $1 \cdot 2$ & 149 & $2 \cdot 3$ \\
\hline Spleen & 0.495 & 0.096 & 0.334 & 0.015 & 0.17 & 0.015 & 0.16 & 0.043 \\
\hline Thyroid & 0.096 & .0 .057 & & & 0.03 & 0.019 & - & \\
\hline Kidney & $I \cdot 96$ & 0.37 & $x \cdot 402$ & 0.119 & 0.62 & 0.12 & 0.70 & 0.25 \\
\hline Adrenals & 0.192 & 0.026 & 0.139 & 0.057 & 0.064 & 0.012 & 0.067 & 0.028 \\
\hline Liver & $9 \cdot 33$ & $1 \cdot 38$ & $7 \cdot 478$ & 0.429 & $3 \cdot 16$ & 0.31 & $3 \cdot 66$ & 0.98 \\
\hline Heart & $I \cdot 72$ & 0.39 & $I \cdot 39$ & 0.176 & 0.581 & O.IOI & 0.595 & 0.071 \\
\hline Lungs & $6 \cdot 48$ & $I \cdot 42$ & 4.89 & 0.926 & 2.91 & 0.42 & $2 \cdot 32$ & 0.33 \\
\hline Thymus & 0.829 & 0.277 & 0.626 & $0.36 r$ & 0.28 & 0.08 & 0.27 & 0.15 \\
\hline
\end{tabular}

*From Kerr, Kennan, Waisman \& Allen (I969).

$\uparrow$ R. Heywood, A. K. Palmer \& J. Cooke (unpublished results).

Growth during the first year. The normal growth pattern of $M$. mulatta is shown in Fig. I. It was expected that weaning would have some slight detrimental effect on body-weight gain, for Zimmermann ( 1969 ) reported that weaning rhesus monkeys from a milk diet to solid monkey diet resulted in a transient period of poor weight gain, but the growth deficit was recovered by day 200 . In our experience, natural weaning at 4,12 and 20 weeks has shown no decrease in body-weight gain, and in some instances the rate of body-weight gain was increased.

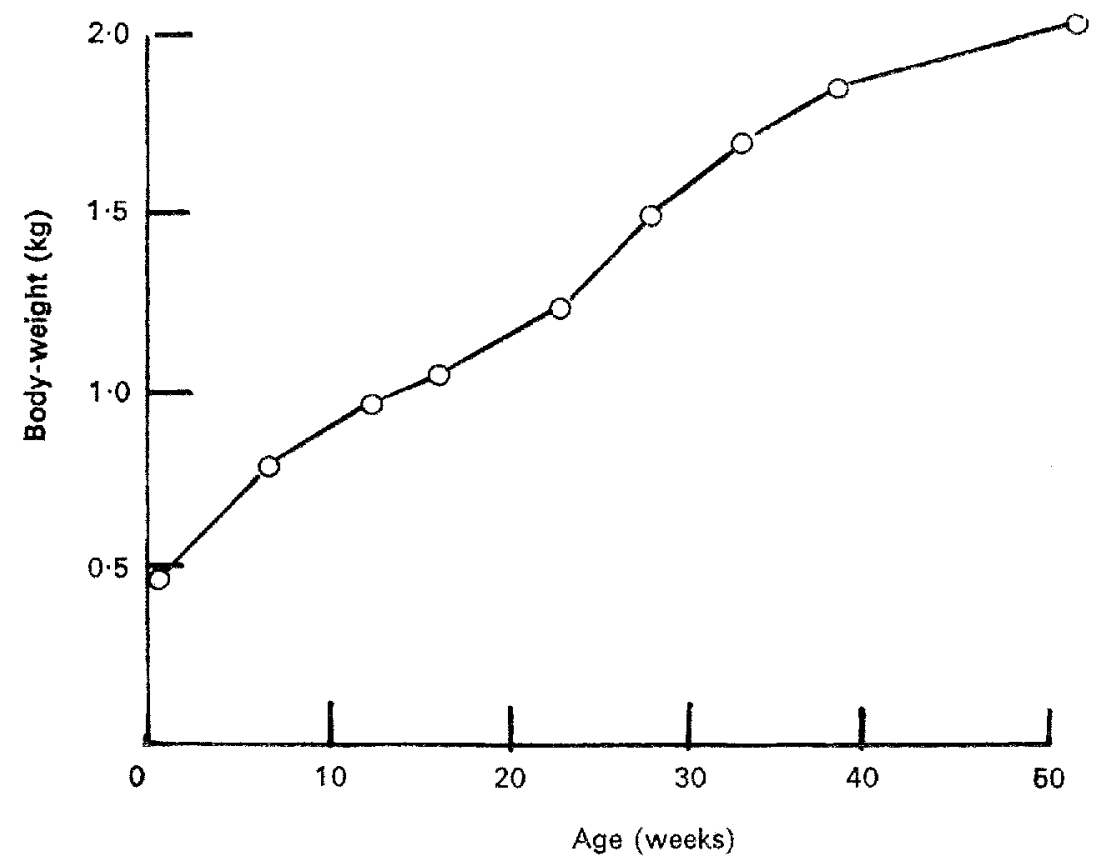

Fig. I. The normal growth curve for the rhesus monkey (Macaca mulatta). 


\section{Nutrition}

Nutrition during gestation. The status of the maternal nutrition affects the foetus; little work has been carried out in this area other than that of Kohrs (1973) and Riopelle, Hill \& Wolf (1973) on the effect of low-protein diet on reproductive performance in rhesus monkeys. High abortion rates and low infant birth weights were recorded when the females were changed from diets providing adequate protein $(\mathrm{I} 40 \mathrm{~g} / \mathrm{kg})$ to low-protein diets (less than $7 \circ \mathrm{g} / \mathrm{kg})$. We give one of the commercially available standard primate diets, FPI (Dixon \& Sons, Ware). This contains $150 \mathrm{~g}$ protein $/ \mathrm{kg}$ and has been shown to be adequate to support reproduction.

Feeding during immediate postnatal period. Infant monkeys can be removed from the mothers immediately after birth and successfully reared. In some instances this has been carried out as a large-scale operation (Valerio, Miller, Innes, Courtney, Pallotta \& Guttmacher, 1969). Commercially available milk substitutes have been proven to be satisfactory. Table 2 shows the comparison of milk analysis between human, cow's and monkey's. There is some evidence that the infant monkeys that are bottle-fed are bigger than those animals that are breast-fed and naturally weaned. It is our policy, if possible, to allow natural breast-feeding and weaning onto a commercial monkey diet by week 20 . The body-weights we record at I year

Table 2. Analysis ( $\mathrm{g} / \mathrm{kg}$ ) of cow's, rhesus monkey's (Macaca mulatta) and human milk, and an artificial preparation

$\begin{array}{lccccc} & \text { Water } & \text { Fat } & \text { Protein } & \text { Carbohydrate } & \text { Ash } \\ \text { Cow } & 870 & 37 & 33 & 48 & 7 \cdot 2 \\ \text { Rhesus monkey } & 870 & 39 & 21 & 59 & 2 \cdot 6 \\ \text { Man } & 870 & 40 & 13 & 65 & 2 \cdot 0 \\ \text { Artificial milk } & 870 & 34 & 17 & 66 & 5 \cdot 0\end{array}$

of age are some $300 \mathrm{~g}$ less than those recorded by Valerio et al. (1969) and Kerr, Scheffler \& Waisman (1969), who give liquid diets for the ist year. There is little to suggest that the increase in weight that they record is accompanied by an increase in skeletal growth and, therefore, bigger cannot be equated with better.

Feeding during rapid growth. Kerr, Scheffler \& Waisman (1969) showed that the intake of liquid diets increased during the first $4-6$ months and with ad lib. feeding reached a peak at day 42 . There was the greatest utilization of the diet between 44 and $35 \mathrm{~d}$. Calculated total energy requirements during this period of rapid growth were approximately $1088 \mathrm{~kJ} / \mathrm{kg}$ body-weight $(260 \mathrm{kcal} / \mathrm{kg})$ at $60 \mathrm{~d}$ of age, falling to about $837 \mathrm{~kJ} / \mathrm{kg}(200 \mathrm{kcal} / \mathrm{kg})$ at I year of age, with an adult value of approximately 460 $\mathrm{kJ} / \mathrm{kg}$ ( I I $\mathrm{kcal} / \mathrm{kg}$ ). Jacobson \& Windle (I960) found the energy intake of a group of monkeys to be $498 \pm 213 \mathrm{~kJ} / \mathrm{kg}$ body-weight (I $9 \pm 5 \mathrm{I} \mathrm{kcal} / \mathrm{kg}$ ) at day 2, I $20 \mathrm{I} \pm$ $255 \mathrm{~kJ} / \mathrm{kg}(287 \pm 6 \mathrm{r} \mathrm{kcal} / \mathrm{kg})$ on day 6 and this rapidly declined to reach $996 \pm \mathrm{r} 42$ $\mathrm{kJ} / \mathrm{kg}\left(23^{8} \pm 34 \mathrm{kcal} / \mathrm{kg}\right)$ at week 5 .

Most of the work in primate nutrition has been directed towards essential amino acids and vitamins. In practice, however, the most important aspect is to maintain water balance. There are considerable dangers associated with excessive dietary 
solute intake; the kidneys have difficulty in maintaining plasma tonicity, and minimal water loss following slight diarrhoeas or sporadic vomiting can result in serious dehydration. It is of importance that water be freely available, for with handreared animals it is difficult to differentiate between hunger and thirst. The changes in plasma osmolarity with age are illustrated in Fig. 2 . With weaning, osmolarity rose rapidly, this being a critical period, but returned to normal values within 3 weeks.

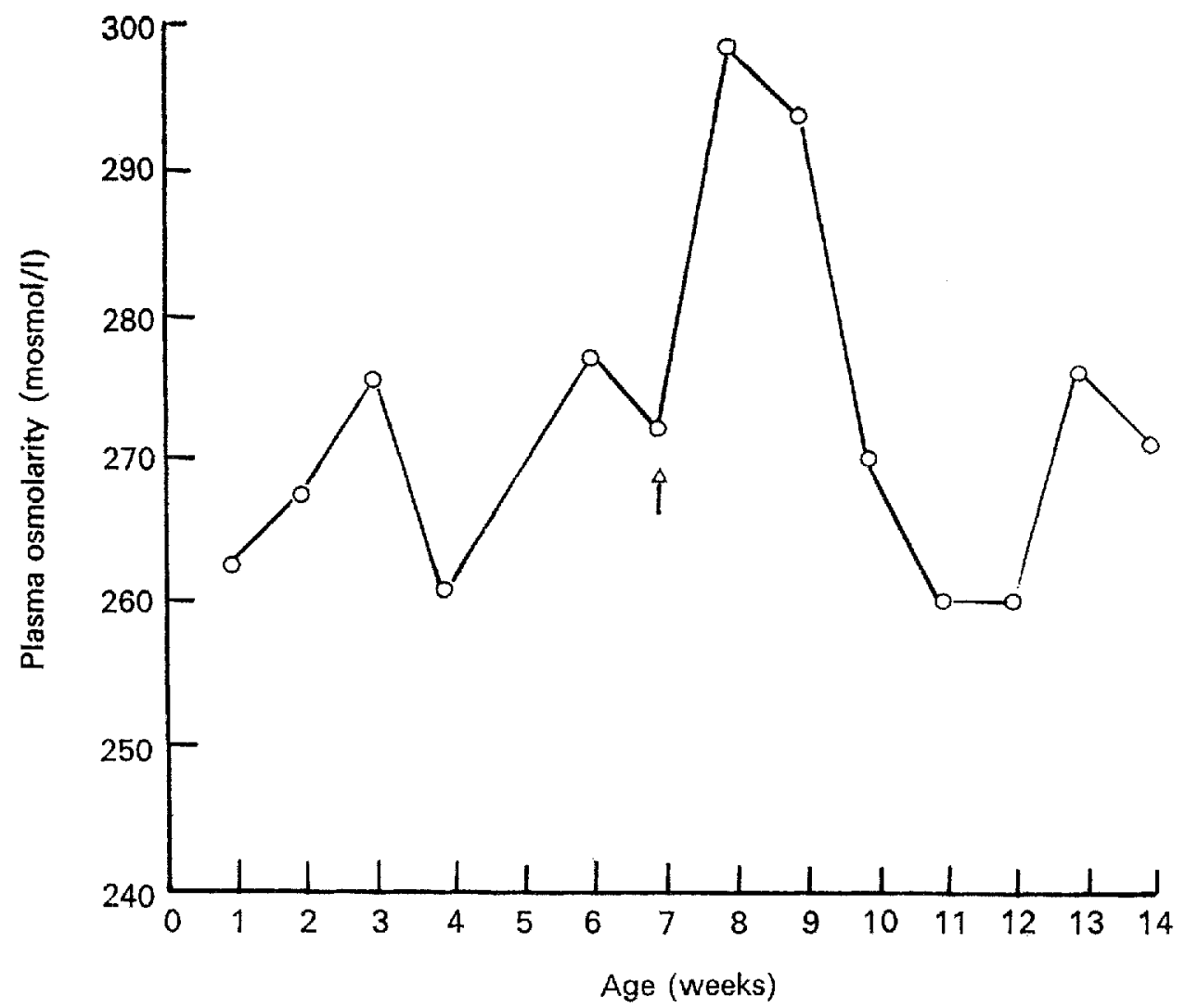

Fig. 2. Changes in plasma osmolarity with age in infant rhesus monkeys (Macaca mulatta), showing the effect of weaning $(\vec{p})$.

Haematological and biochemical changes with age. Changes in the haemogram occur in the first weeks of life. The rhesus monkey is born with high erythrocyte count, packed cell volume and haemoglobin values, which fall during the first 2 weeks. Inversion of the neutrophil and lymphocyte counts and ratios occurs within the first $40 \mathrm{~d}$. These findings are consistent with those reported by Kerr, Scheffler $8 x$ Waisman ( 1969), Valerio et al. (I 969) and Martin, McGowan \& Loeb (1973).

Biochemical values in adult monkeys have been established, but similar data for infant monkeys are not available. We have investigated serum alkaline phosphatase (SAP) levels in relation to body-weight and age. These data suggest that the SAP 
values fall from day 200 to day $35^{\circ}$. There is evidence that during the adolescent growth spurt there is a rise in SAP values.

\section{Conclusion}

The development of the neonate primate as a model for the study of infantile disease and growth is of limited value; but it might prove of greater interest for nutritional work. The development of the single-cell proteins poses new problems particularly with respect to their safety, and I would suggest that here the monkey might prove a useful research tool.

\section{REFERENCES}

Harris, R. S. (1970). Feeding and Nutrition of Non-human Primates. New York 8 London: Academic Press.

Jacobson, H. N. \& Windle, W. F. (1960). Biologia Neonat. 3, 105.

Kerr, G. R. (1972). Physiol. Rev. 52, 4I5.

Kerr, G. R., Kennan, A. L., Waisman, H. A. \& Allen, J. R. (1969). Growth 33, 201.

Kerr, G. R., Scheffler, G. \& Waisman, H. A. (r969). Growth 33, 185.

Kohrs, M. B. (1973). Fedn Proc. Fedn Am. Socs exp. Biol. 32, g0 r Abstr.

Martin, D. P., McGowan, M. J. \& Loeb, W. F. (1973). Lab, Anim. Sci. 23, 194.

Price, R. A., Anver, M. R. \& Garcia, F. G. (1972). Vet. Path. 9, 30 r.

Riopelle, A. J., Hill, C. W. \& Wolf, R. H. (1973). Fedn Proc. Fedn Am. Socs exp. Biol. 32, 9orAbstr. Valerio, D. A., Miller, R. L., Innes, J. R. M., Courtney, K. D., Pallotta, A. J. \& Guttmacher, R. M. (1969). Management of a Laboratory Breeding Colony of Macaca mulatta. New York \& London: Academic Press.

Zimmermann, R. R. (1969). Lab. Anim. Care 19, 644. 